\title{
Investigating Factors of Slope Failure for Different Landsliding Sites in Murree Area, Using Geomatics Techniques
}

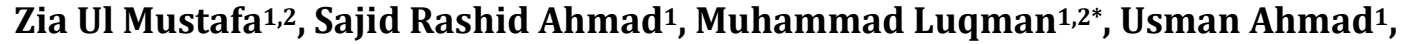 \\ Samiullah Khan', Muhammad Nawaz ${ }^{3}$, Asif Javed 3,4 \\ ${ }^{1}$ College of Earth and Environmental Sciences, University of the Punjab, Lahore, Pakistan \\ ${ }^{2}$ The Urban Unit, Urban Sector Planning and Management Services Unit (Pvt.) Ltd., Lahore, Pakistan \\ ${ }^{3}$ Department of Space Science, University of the Punjab, Lahore, Pakistan \\ ${ }^{4}$ Punjab Group of Colleges, Pattoki Campus, Kasur, Pakistan \\ Email: ${ }^{\text {m luqman1@yahoo.com }}$
}

Received 13 September 2015; accepted 13 October 2015; published 16 October 2015

Copyright (C) 2015 by authors and Scientific Research Publishing Inc.

This work is licensed under the Creative Commons Attribution International License (CC BY).

http://creativecommons.org/licenses/by/4.0/

(c) (i) Open Access

\begin{abstract}
Throughout the mountainous part of Pakistan, Murree is considered to host the worst slide affected areas. Landslide risk assessment, mapping and analysis is a labour intensive and time consuming work by using conventional field based methods. In this study Geomatics techniques have been applied on digital data such as satellite image and DEM, to investigate some possible causes of slope failure in selected landslide risk zones. The Remote sensing technology and GIS capabilities have been implemented using Landsat TM $(30 \mathrm{~m})$ multispectral data and Aster DEM (30 m). Satellite image and digital elevation model have been used to generate rock type map, aspect map, streams order map and slope map. The possible factors of slope failure for different zones of land sliding have been predicted by integrating information from all maps. It has been found that major causes of slope failure have been addressed, also it has been noted that water is the most dominant factor to cause land sliding in Murree area. Results are available for supporting hazard studies, disaster management and future development plans.
\end{abstract}

\section{Keywords}

Landslide, Pakistan, Geomatics, Hazard, Landsat, DEM, GIS

\section{Introduction}

Throughout the mountainous part of Pakistan, Murree is considered to host the worst slide affected areas [1].

"Corresponding author.

How to cite this paper: Mustafa, Z.U., et al. (2015) Investigating Factors of Slope Failure for Different Landsliding Sites in Murree Area, Using Geomatics Techniques. Journal of Geoscience and Environment Protection, 3, 39-45.

http://dx.doi.org/10.4236/gep.2015.38004 
The available literature and data, together with the field observations, show that many factors known to cause landslides are present in Murree. These include young and immature geology with highly erodible soils and rocks, steep and irregular slopes, abundant and seasonally intense monsoon rainfall, active freeze and thaw, evidence of the older landslides, and all extensive human activities, including deforestation, quarrying, building and road construction [2]. Some Physiographic characteristics including slope, aspect, drainage, geological character relative relief, landuse and land cover play a major role in deciding the potential sites for slope failure. Such analysis is a complex task involving numerous factors affecting slope failure and requires inclusion of several parameters and analytical techniques [3]-[15].

In contrast to the conventional methods of geological fieldwork which is time consuming, expensive and complex logistics, Geomatics techniques offer efficient, faster and low cost applications to supplement the preliminary geologic and geomorphologic investigations. Data collection, analysis and interpretation have been often proved to be difficult, by using conventional field survey only; furthermore in previous studies, geological and geomorphological mapping required long time and considerable costs, for being carried out at a large scale [16]. In this paper geomatics techniques have been applied on digital data such as satellite image and digital elevation model integrated with survey data, to investigate the possible factors of slope failure for different landsliding sites. False color composites of Landsat TM image and different DEM derivatives of ASTER DEM have been used for this study.

In Murree area, the hill slopes are moderately steep and vary from 16 to 40 degree. An increase in slope steepness leads to a decrease in the shear strength of the material that triggers landslides. Also in those areas where the slopes are steep specifically along the streams, roads and disturbed slopes, the problem of land sliding is a recurrent phenomenon. Rainfall is the major factor responsible for most of the landslides in the Murree area. Therefore in the study area, rainfall is considered to be the most important causative factor for a landslide problem [1].

Lithology is considered as primary driving force for slope failure in all over the world. Clear cut landslide frequency is related to surficial material, bedrock lithology, horizontal slope curvature, soil type, slope angle, slope position and slope morphology [1] [17].

The following major causes of slope failure have been identified and listed as:

- Geological conditions including material nature (soil/rock) and discontinuities.

- Surface and subsurface ground water conditions.

- Climatic and Environmental changes.

- Seismic disturbance including Earthquake, vibration and trigger action.

- Effects of deforestation and forestation [18].

\section{Study Area}

Murree is a hill station, summer resort and the administrative center of Murree Tehsil, which is a subdivision of Rawalpindi District (Figure 1) and includes the Murree Hills. Murree lies 50 kilometers northeast of Pakistan's capital Islamabad at a comfortable altitude of 7500 feet (2286 meters) in the Himalayan foothills at $33^{\circ} 54^{\prime} 30^{\prime \prime}$ North latitude and $73^{\circ} 26^{\prime}$ East longitude, http://murreehill.com.

Murree, lovingly called "the Queen of the hills", lies in the sub-Himalayan mountain region [1] [19]. Murree is one of the most developed hill stations in the country characterized by the assets of pine forest, parks, restaurants, chair lifts, cable cars and hiking tracks [20]. A total of about 1880 ha of the land is under various uses, out of which $70 \%$ is tree cover, $7 \%$ agricultural use, $6 \%$ allocated for defense purpose and the rest for commercial, civic and residential uses [1] [19]. The study area is located along Murree-Kohala-Muzaffarabad Road and extends from Murree to Kohala. The area covers survey of Pakistan Topographic sheet No. 43 G/5, 43 G/9, 43 F/12.

\section{Materials and Methods}

\subsection{Data}

The Landsat Thematic Mapper image (Row\#150, Path\#036) of date September 20, 1992, ASTER DEM, Geological map containing information about rock types and Survey data of different landslide sites containing information about unstable landsliding zones and potentially unstable landsliding zones, has been used in this study. The sources and acquisition date of data is summarized in Table 1. 


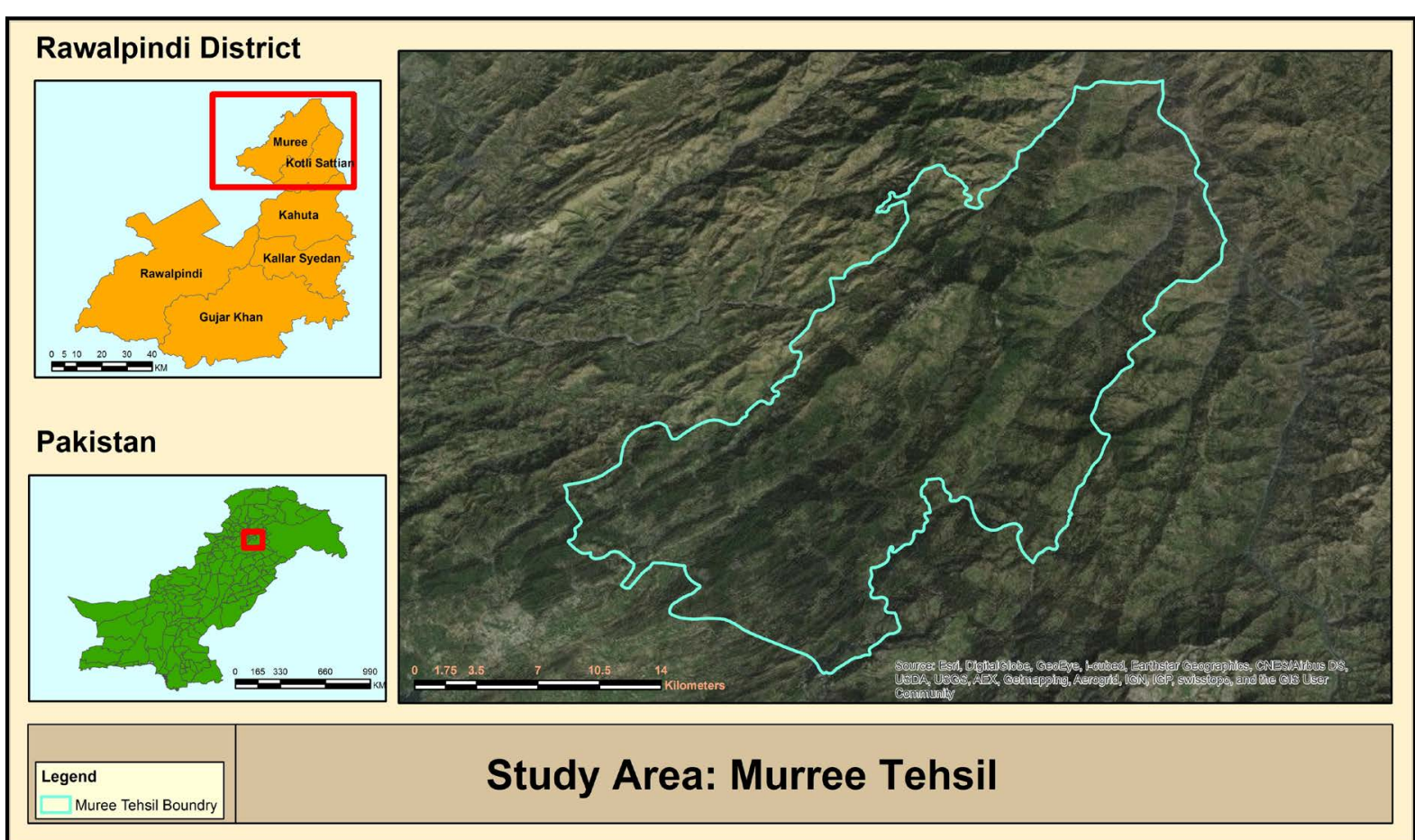

Figure 1. Study area.

Table 1. Detail of used data.

\begin{tabular}{ccc}
\hline Data & Acquisition Date & Source \\
\hline Landsat TM & 20 September, 1992 & $\underline{\mathrm{ftp}: / / \mathrm{ftp} . \text { glcf.umd.edu }}$ \\
ASTER & 2006 & $\underline{\mathrm{ftp} / / \text { ftp.glcf.umd.edu }}$ \\
Geological Map & 1990 & Institute of Geology, PU \\
Landslide Data & 1990 & Institute of Geology, PU \\
\hline
\end{tabular}

\subsection{Data Acquisition and Preparation}

The data used for the study are as follows (Figure 2):

Landsat TM image

ASTER DEM

Survey Data of different landslide sites

Geological Map

Landsat TM image (Path\#150, Row\#036) of Date September 20, 1992 has been freely downloaded.

The image of 1992 has been obtained because landslide survey data of 1990 is available and used for study. Six bands of Landsat TM excluding the thermal band have been stacked and particular area of interest is cut from the image. All these steps have been performed (Figure 3) using ERDAS IMAGINE.

ASTER DEM ( 2 tiles, $33^{\circ} \mathrm{N} 73^{\circ} \mathrm{E}$ and $34^{\circ} \mathrm{N} 73^{\circ} \mathrm{E}$ ) has been freely downloaded.

These two tiles have been mosaicked and particular area of interest has been cut using ArcGIS software. Survey data of different landslide sites have been obtained from the results of already conducted study and field survey in same area. The landslide map has been scanned and georefferenced, then particular landslide features such as unstable zones, potentially unstable zones, stable zones and rock types have been digitized in separate shapefiles to use in analysis. All these steps have been performed using ArcGIS.

\subsection{Landsliding Sites Description}

The survey data contains information about land sliding sites in study area and this data was collected by con- 


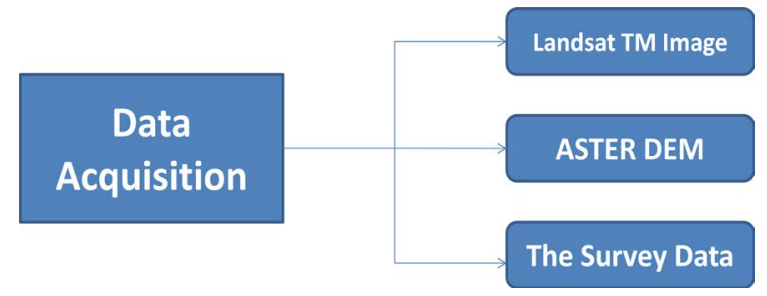

Figure 2. Data acquisition.

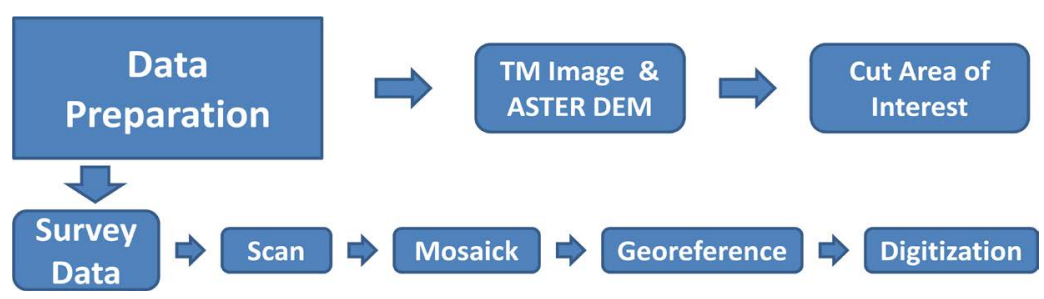

Figure 3. Flow chart of study.

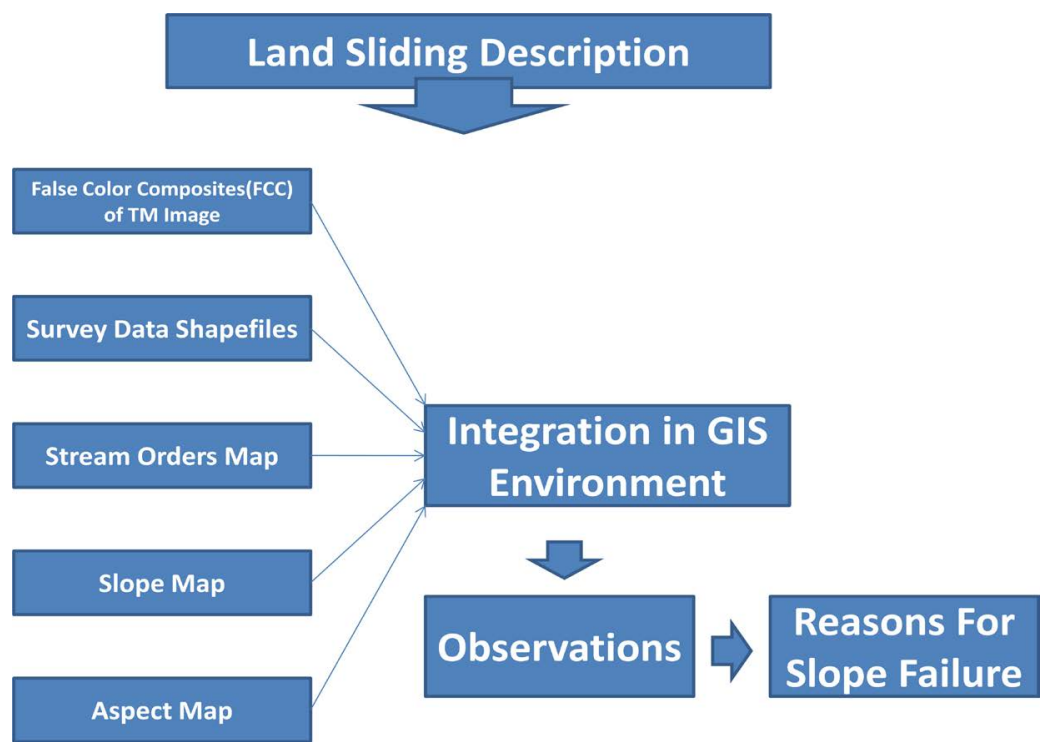

Figure 4. Flow chart of analysis.

ducting field survey physically. The technical description and possible causes of these land sliding sites have been discussed here using Landsat image and ASTER DEM. Satellite image has been used for the general assessment of study area using false color composites (FCC) and to observe the presence and status of vegetation on a particular site, as Landsat band 4 is much suitable for vegetation discrimination from other landcover features. Different DEM derivatives such as stream order map, slope map, aspect map and shaded DEM have been prepared and used for technical description of different land sliding sites. Integration of survey data with image analysis and DEM analysis in ArcGIS provided the capability to assess the possible reasons of different land sliding sites. Slope and Aspect maps has been prepared using "Raster surface" tools, present in 3D Analyst tools of Arc Map. Streams order map has been prepared using "hydrology" module present in Spatial Analyst Tools of Arc Map. All these steps are shown in Figure 4.

\section{Results and Discussions}

As the survey data contains information about land sliding sites in the study area, it spatially describes the position and orientation of unstable land sliding zones and potentially unstable land sliding zones. This data was collected by conducting field survey physically. The technical description and possible causes of these land 
sliding sites have been discussed here using Landsat TM image and ASTER DEM. Satellite image has been used for the general assessment of study area using false color composites (FCC) and to observe the presence and status of vegetation on a particular site, as Landsat TM band 4 is much suitable for vegetation discrimination from other landcover features.

Different DEM derivatives such as stream order map, slope map, aspect map and colored DEM have been prepared and used for technical description of different land sliding sites. From survey map land sliding unstable zones and potentially unstable zones have been digitized in separate shapefiles. These shapefiles have been overlaid over the satellite image, DEM, aspect map, slope map and stream orders map in ArcGIS. Slope and Aspect maps has been prepared using "Raster surface" tools, present in 3D Analyst module of Arc Map. Streams order map has been prepared using "Hydrology” module present in Spatial Analyst Tools of Arc Map.

Integration of survey data with image analysis and DEM analysis in ArcGIS environment provided the capability to assess the possible reasons of different land sliding sites. Careful observations have been taken by considering all these layers at a time. There are 20 unstable zones and 20 potentially unstable zones, which are shown in Table 2 and Table 3 respectively. Unstable zones have been tagged serial number from U1 to U20, and potentially unstable zones have been tagged from P1 to P20. Observations and description of every zone have been described separately.

Some possible factors have been addressed that are responsible to cause landslides. Streams order layer contains information about the number of water channels passing through study area. Higher the stream order, larger will be water channel. More the number of streams pass through an area and higher the order of streams passing through a zone the area will be more unstable and likely to slide. Sometime small order but large number of streams pass through a particular zone, this excess of water flow is responsible for slope failure.

Presence of vegetation is the sign of stability. Landsat image have been used to highlight the presence of vegetation and its status. Some zone aspects lie in such direction that vegetation cannot sustain on that area so absence of vegetation is also the cause of unstability. Some zones carry small order streams but their slope angle is so much higher that slope gradient can cause the land to slide. Some zones have few of these slope controlling

Table 2. Unstable landsliding zones description.

\begin{tabular}{|c|c|c|c|c|c|}
\hline $\begin{array}{l}\text { Unstable } \\
\text { Zone(U) }\end{array}$ & $\begin{array}{c}\text { Area } \\
\text { (Meter sq) }\end{array}$ & $\begin{array}{l}\text { Slope Angle } \\
\text { (Degree) }\end{array}$ & Stream Order & Rock Type & Reasons of Slope Failure \\
\hline U1 & 56,070 & $4-33$ & $1,2,3$ & Argillaceous Sand Stone & Water flow \& Slope Angle \\
\hline $\mathbf{U 2}$ & 40,384 & $12-33$ & $1,2,3$ & Argillaceous Sand Stone & Water flow \& Slope Angle \\
\hline U3 & 21,774 & $12-33$ & $1,2,3$ & Argillaceous Sand Stone & Water flow \& Slope Angle \\
\hline U4 & 9477 & $19-33$ & $1,2,3,4$ & Argillaceous Sand Stone & Water flow \& Slope Angle \\
\hline U5 & 19,787 & $12-19$ & $1,2,3$ & Argillaceous Sand Stone & Water flow \& Lack of vegetation \\
\hline U6 & 29,026 & $4-26$ & $1,2,3$ & Fine to medium Sand Stone & Water flow \& Slope Angle \\
\hline U7 & 66,580 & $4-26$ & $1,2,3$ & Argillaceous Sand Stone & Water flow \& Slope Angle \\
\hline U8 & 4758 & $12-26$ & 1,2 & Fine to medium Sand Stone & Water flow \& Slope Angle \\
\hline U9 & 4742 & $19-26$ & 1,2 & Fine to medium Sand Stone & Water flow \& Lack of vegetation \\
\hline U10 & 11,840 & $19-33$ & $1,3,4$ & Fine to medium Sand Stone & Water flow \& Slope Angle \\
\hline U11 & 1244 & $19-26$ & $1,2,3$ & Fine Sand Stone (Silty) & Water flow \& Lack of vegetation \\
\hline U12 & 25,070 & $19-42$ & $1,2,3$ & Fine to medium Sand Stone & Water flow \& Slope Angle \\
\hline U13 & 7495 & $19-26$ & 1,2 & Fine to medium Sand Stone & Excess of water flow in surrounding \\
\hline U14 & 9612 & $26-33$ & $1,2,3$ & Fine to medium Sand Stone & Water flow \& Slope Angle \\
\hline U15 & 21,845 & $12-42$ & 1 & Fine to medium Sand Stone & Slope Angle\& Lack of vegetation \\
\hline U16 & 24,342 & $19-33$ & $1,2,3$ & Fine to medium Sand Stone & Water flow \& Slope Angle \\
\hline U17 & 45,470 & $12-33$ & $1,2,3,4$ & Fine to medium Sand Stone & Water flow \& Slope Angle \\
\hline U18 & 23,819 & $19-26$ & $1,2,3$ & Fine to medium Sand Stone & Water flow \& Slope Angle \\
\hline U19 & 5700 & $4-19$ & 1,2 & Fine to medium Sand Stone & Water flow \& Lack of vegetation \\
\hline U20 & 10,678 & $4-26$ & 1,2 & Fine to medium Sand Stone & Water flow \& Lack of vegetation \\
\hline
\end{tabular}


Table 3. Potentially unstable zones description.

\begin{tabular}{|c|c|c|c|c|c|}
\hline $\begin{array}{l}\text { Potentially } \\
\text { Unstable Zone }\end{array}$ & $\begin{array}{c}\text { Area } \\
\text { (Meter Sq) }\end{array}$ & $\begin{array}{c}\text { Slope Angle } \\
\text { (Degree) }\end{array}$ & Stream Order & Rock Type & Reasons of Slope Failure \\
\hline $\mathbf{P 1}$ & 321,445 & $20-30$ & $1,2,3,4,5$ & Argillaceous Sand Stone & Water flow and Slope Angle \\
\hline $\mathbf{P 2}$ & 34,973 & $15-25$ & 1,2 & Argillaceous Sand Stone & Water flow around and Slope Angle \\
\hline P3 & 144,747 & $20-30$ & $1,2,3$ & Argillaceous Sand Stone & Water flow and Slope Angle \\
\hline $\mathbf{P 4}$ & 60,152 & $10-25$ & $1,2,3$ & Argillaceous Sand Stone & Water flow and Slope Angle \\
\hline P5 & 54,300 & $10-25$ & $1,2,3$ & Argillaceous Sand Stone & Water flow and Slope Angle \\
\hline P6 & 23,469 & $15-25$ & $1,2,3,4$ & Argillaceous Sand Stone & Water flow and Slope Angle \\
\hline P7 & 14,659 & $12-19$ & 1,2 & Fine to medium Sand Stone & Water flow in surrounding \\
\hline $\mathbf{P 8}$ & 6427 & $12-19$ & 1,2 & Argillaceous Sand Stone & Lack of vegetation \\
\hline P9 & 5864 & $12-26$ & 1,2 & Fine Sand Stone (Silty) & Rock type and Slope angle \\
\hline $\mathbf{P 1 0}$ & 5153 & $12-26$ & 1,2 & Fine Sand Stone (Silty) & Rock type and Slope angle \\
\hline P11 & 7245 & $26-42$ & $1,3,4$ & Fine to medium Sand Stone & Water and Slope Angle \\
\hline P12 & 25,769 & $12-33$ & 1,2 & Fine to medium Sand Stone & Water and Slope Angle \\
\hline P13 & 25,950 & $12-33$ & 1 & Fine to medium Sand Stone & Less vegetation \& Slope Angle \\
\hline P14 & 13026 & $12-26$ & 1,2 & Fine to medium Sand Stone & Water and Slope Angle \\
\hline P15 & 3908 & $12-33$ & 1,3 & Fine to medium Sand Stone & Water and Slope Angle \\
\hline P16 & 3221 & $12-26$ & 1,2 & Fine to medium Sand Stone & Less vegetation and Slope Angle \\
\hline $\mathbf{P 1 7}$ & 6188 & $19-33$ & 1 & Fine to medium Sand Stone & Less vegetation and Slope Angle \\
\hline P18 & 3385 & $19-33$ & 1,2 & Fine to medium Sand Stone & Water and Slope Angle \\
\hline P19 & 1836 & $19-33$ & 1 & Fine to medium Sand Stone & Less vegetation and Slope Angle \\
\hline $\mathbf{P 2 0}$ & 7691 & $19-33$ & 1,2 & Fine to medium Sand Stone & Less vegetation and Slope Angle \\
\hline
\end{tabular}

factors, so these areas have the potential to landsliding, and can slide any time when conditions fulfilled. Some zones contain all the causes of slope failure so these are most unstable zones.

\section{Conclusion}

It is concluded that Geomatics techniques can be very useful for landslide studies. Applying Geomatics techniques on digital data integrated with survey data can be used very effectively for landslide hazard zone mapping at medium scale. Also some possible factors can be addressed that are responsible to cause landslides. It has been found that some major causes of slope failure have been addressed using satellite imagery and digital elevation data integrated with survey data, also it has been noted that the larger the number of streams passing through an area and the higher the order of stream passing through a zone, the area will be more unstable, so water is the most dominant factor to cause land sliding in Murree area. Also some zones aspect lies in such direction that vegetation cannot sustain on that area so absence of vegetation is also the cause of unstability. Some zones carry small order streams but their slope angle is so much higher that causes the land to slide. Accuracy of mapping and prediction can be increased by using high resolution data and real time survey data.

\section{References}

[1] Rehman, A.U., Khan, A.N. and Collins, A.E. (2010) Causes and Extent of Environmental Impacts of Landslides Hazards in the Himalayan Region: A Case Study of Murree, Pakistan. Springer Science, 57, 413-434.

[2] Khan, A.N. (2000) Landslide Hazard and Policy Response in Pakistan: A Case Study of Murree, Pakistan. Science Vision, 6, 35-48.

[3] Choubey, V.D. and Litoria, P.K. (1990) Terrain Classification and Land Hazard Mapping in Kalsi-Chakrata Area (Garhwal Himalaya), India. ITC Journal, 1, 65-68.

[4] Gupta, R.P. and Joshi, B.C. (1990) Landslide Hazard Zonation Using the GIS Approach-A Case Study from the Ramganga Catchment, Himalayas. Engineering Geology, 28, 119-131. 
http://dx.doi.org/10.1016/0013-7952(90)90037-2

[5] Pachauri, A.K. and Pant, M. (1992) Landslide Hazard Mapping Based on Geological Attributes. Engineering Geology, 32, 81-100. http://dx.doi.org/10.1016/0013-7952(92)90020-Y

[6] Soeters, R. and van Westen, C.J. (1996) Slope Instability Recognition Analysis and Zonation. In: Turner K.T. and Schuster, R.L., Eds., Landslides: Investigation and Mitigation, Special Report No. 247, Transportation Research Board National Research Council, Washington DC, 129-177.

[7] Van Westen, C.J., Rengers, N., Terlien, M.T.J. and Soeters, R. (1997) Prediction of the Occurrence of Slope Instability Phenomena through GIS Based Hazard Zonation. Geologische Rundschau, 86, 404-414. http://dx.doi.org/10.1007/s005310050149

[8] Aleotti, P. and Chowdhury, R. (1999) Landslide Hazard Assessment: Summary Review and New Perspectives. Bulletins of Engineering Geology and the Environment, 58, 21-44. http://dx.doi.org/10.1007/s100640050066

[9] Van Westen, C.J. (2000) The Modelling of Landslide Hazards Using GIS. Geophysics, 21, 241-255.

[10] Dai, F.C. and Lee, C.F. (2002) Landslide Characteristics and Slope Instability Modelling Using GIS, Lantau Island, Hong Kong. Geomorphology, 42, 213-238. http://dx.doi.org/10.1016/S0169-555X(01)00087-3

[11] Lin, M.L. and Tung, C.C. (2003) A GIS-Based Potential Analysis of the Landslides Induced by the Chi-Chi Earthquake. Engineering Geology, 71, 63-77. http://dx.doi.org/10.1016/S0013-7952(03)00126-1

[12] Mathew, J., Jha, V.K. and Rawat, G.S. (2007) Weights of Evidence Modelling for Landslide Hazard Zonation Mapping in Part of Bhagirathi Valley, Uttarakhand. Current Science, 92, 628-638.

[13] Sharma, M. and Kumar, R. (2008) GIS-Based Landslide Hazard Zonation: A Case Study from the Parwanoo Area, Lesser and Outer Himalaya, H.P., India. Bulletins of Engineering Geology and the Environment, 67, 129-137. http://dx.doi.org/10.1007/s10064-007-0113-2

[14] Chauhan, S., Sharma, M. and Arora, M.K. (2010) Landslide Susceptibility Zonation of the Chamoli Region, Garhwal Himalayas, Using Logistic Regression Model. Landslides, 7, 411-423. http://dx.doi.org/10.1007/s10346-010-0202-3

[15] Chandel, V.B.S., Brar, K.K. and Chauhan, Y. (2011) RS \& GIS Based Landslide Hazard Zonation of Mountainous Terrains, A Study from Middle Himalayan Kullu District, Himachal Pradesh, India. International Journal of Geomatics and Geosciences, 2, 121-132.

[16] Lucchesi, S., Giardino, M. and Perotti, L. (2012) Applications of High-Resolution Images and DTMs for Detailed Geomorphological Analysis of Mountain and Plain Areas of NW Italy. European Journal of Remote Sensing, 46, 216233.

[17] Slaymaker, O. (2001) The Role of Remote Sensing in Geomorphology and Terrain Analysis in the Canadian Cordillera. Journal of Applied Geosciences, 3, 11-17. http://dx.doi.org/10.1016/s0303-2434(01)85016-9

[18] Ali, Z. and Saeed, A. (2012) Geotechnical Studies of Dewal Landslide along Murree-Muzzafarabad Road, Pakistan. B.S. Thesis, Institute of Geology, University of the Punjab, Lahore.

[19] Khan, A.N., Jalloh, S. and Moughtin, C. (1994) Towards an Appraisal of Landslide Hazard Reduction Programme in Murree, Pakistan. Pakistan Journal of Geography, 4, 15-30.

[20] Ishfaq, M. (1999) Application of GIS and RS to Slope Instability Problems (Landsliding). Northeastern Murree, NWFP, Pakistan. 